\title{
Economic basis for the Nordic Total Merit Index
}

\author{
M. Kargo, ${ }^{*} \dagger^{1}$ L. Hjortø, $†$ M. Toivonen, $\ddagger$ J. A. Eriksson,§ G. P. Aamand, $† \#$ and J. Pedersen $†$ \\ *Department of Molecular Biology and Genetics, Center for Quantitative Genetics and Genomics, Aarhus University, PO Box 50,8830 Tjele, \\ Denmark \\ †Knowledge Centre for Agriculture, Agro Food Park 15, DK-8200 Aarhus N, Denmark \\ †Faba, PO Box 95, 15871 Hollola, Finland \\ §Växa, PO Box 210, 10124 Stockholm, Sweden \\ \#Nordic Cattle Genetic Evaluation, Agro Food Park 15, DK-8200 Aarhus N, Denmark
}

\section{ABSTRACT}

Within a group of cooperating countries, all breeding animals are judged according to the same criteria if a joint breeding goal is applied in these countries. This makes it easier for dairy farmers to compare national and foreign elite bulls and may lead to more selection across borders. However, a joint breeding goal is only an advantage if the countries share the same production environment. In this study, we investigated whether the development of a joint breeding goal for each of the major dairy cattle breeds across Denmark, Finland, and Sweden would be an advantage compared with national breeding goals. For that purpose, economic values for all breeding goal traits in the 3 countries were derived, and estimated rank correlations between bulls selected for a national breeding goal and a joint breeding goal were compared. The economic values within country were derived by means of an objective bio-economic model, and the basic situation in each of the 3 production environments was based on an average dairy cattle herd with regard to production system, production level, and management strategy. The common Nordic economic values for each trait were calculated as the average of that specific trait in each of the 3 production environments. Balanced breeding goals were obtained in all situations because the derived economic values for traits related to health, fertility, milk production, and longevity were sizeable. For both Nordic Red Dairy Cattle and Nordic Holstein, the estimated rank correlations between bulls selected for a national breeding goal and a joint breeding goal were very high. Thus, a joint breeding goal within breed is feasible for Denmark, Finland, and Sweden.

Key words: economic value, breeding goal, dairy production, phenotypic level

Received November 8, 2013.

Accepted September 2, 2014.

${ }^{1}$ Corresponding author: morten.kargo@agrsci.dk

\section{INTRODUCTION}

Four major factors contribute to the usefulness of selection indices across lines of the same breed in different countries: difference in breeding goals, genotypeby-environment interaction $(\mathbf{G} \times \mathbf{E})$, difference in trait definition, and difference in genetic evaluation. The breeding goal defines which traits are to be improved and how much weight is given to each trait. In dairy cattle breeding, the weighting factors are usually economic values (Groen et al., 1997). Economic values are functions of the production circumstances. Breeding goals might differ because of different production circumstances, but they are ultimately something to be decided upon by the breeding organizations, and hence may ignore some variation in production circumstances between herds. If $\mathrm{G} \times \mathrm{E}$ exists, genes and their effects behave differently across environments (Lynch and Walsh, 1998). Therefore, phenotypes recorded in a different environment have lower information value. Similarly, differences in trait definitions and differences in genetic evaluations cause reduced efficiency of selection across populations and lower the value of information.

The establishment of Nordic Cattle Genetic Evaluation (NCGE) in 2002 and the establishment of a Danish-Finnish-Swedish AI organization have nullified the previous differences in trait definitions and genetic evaluations. Attempts to find $\mathrm{G} \times \mathrm{E}$ in and across the Nordic countries have resulted in small differences (e.g., Kolmodin, 2003), which suggests that the major part of the genes have the same effect within breed across all countries. The remaining question is whether a joint breeding goal within breed is feasible for the entire region.

In countries with the same production environment, the main advantage of a joint breeding goal is higher genetic gain as a result of higher selection intensity due to a larger population size. Using the same methodology across countries, Kulak et al. (2004) derived economic values for some of the breeding goal traits and some of the breeds in Denmark, Finland, Norway, and Sweden. On the basis of their results, they concluded 
Table 1. Assumed feed prices $(€ / \mathrm{kg})$ for the 3 production environments

\begin{tabular}{lccc}
\hline Feed & Denmark & Finland & Sweden \\
\hline Grain & 0.17 & 0.19 & 0.17 \\
Soy & 0.23 & 0.25 & 0.25 \\
Calf mixture & 0.20 & 0.22 & 0.20 \\
\hline
\end{tabular}

that the differences in the economic values were not an impediment to a closer co-operation between the Nordic countries.

Based on this background information, we reasoned that the development of a joint breeding goal for each of the major dairy cattle breeds across Denmark, Finland, and Sweden would be an advantage. We tested this hypothesis by comparing estimated rank correlations between bulls selected for a national breeding goal and a joint breeding goal. To do so, we derived economic values for all breeding goal traits in the 3 countries.

\section{MATERIALS AND METHODS}

\section{Model}

The economic values were derived by means of a static, deterministic bio-economic model of dairy farming. The model is described in details in Pedersen et al. (2008) and is accessible to the public (NAV, 2014). The input parameters included average phenotypic levels for all traits and basic prices of all input and output factors for 2 breeds [Red Dairy Cattle (RDC) and Holstein] in 3 production environments (Denmark, Finland, and Sweden). Assumptions on the phenotypic levels for a given combination of breed and production environment are averages of phenotypic records from all cows falling into this particular combination of breed and country that have EBV in 2007. The averages of the phenotypic records come from national cattle databases and statistical publications as given in Pedersen et al. (2008). Basic prices of all input and output factors were national market prices from 2007 as described in Pedersen et al. (2008). The pricing system in northern Finland differs substantially from that in central and southern Finland. The differences are mainly due to higher milk prices and higher feed costs in northern Finland. We chose to use prices from central and southern Finland.

\section{Production System, Production Level, and Feeding of Cows}

An average dairy cattle herd with regard to production system, production level, and management strategy formed the background for the basic situation in each of the 3 production environments. Beef production was evaluated as an integrated part of the dairy cattle production system. The economic values were derived at the herd level; that is, only factors directly connected to the animals were considered. All groups of animals were fed according to requirements, for example, maintenance, growth, milk production, and fetal development. The energy requirements for milk, fat, and protein production were based on the study by Sjaunja et al. (1990) and adjusted for the marginal feed utilization that results from a genetically improved yield capacity. The marginal feed utilization was assumed to be $70 \%$ based on the considerations of Østergaard and Neimann-Sørensen (1989) and Veerkamp et al. (1995). The assumed feed prices are shown in Table 1.

Females were inseminated until pregnancy or until $168 \mathrm{~d}$ after first insemination (8 estrus periods). Pregnant heifers were sold internally or externally at the assumed price of springing heifers (Table 2). Barren females were slaughtered.

Heifers were purchased if there was a deficit of pregnant heifers born within the herd; thus, there were always enough heifers available for replacement. Therefore, cow replacement rate was independent of the number of heifers born within the herd. We assumed that $3 \%$ of the liveborn heifer calves died, $5 \%$ of the live born bull calves died, and $4 \%$ of the cows died each year. For all dead animals, the costs of disposal were taken into account.

\section{Traits and Price Assumptions}

Economic values were derived for 27 breeding goal traits. The derivations were based on average market prices from spring 2007. The herds generated revenues

Table 2. Assumed prices of springing heifers (€/head) and slaughtered females $(€ / \mathrm{kg}$ of carcass) for the 3 production environments

\begin{tabular}{lccc}
\hline Item $^{1}$ & Denmark & Finland & Sweden \\
\hline Springing heifer, RDC & 1,160 & 1,220 & 1,160 \\
Springing heifer, HOL & 1,160 & 1,350 & 1,160 \\
Slaughtered heifer & 2.32 & 3.12 & 2.90 \\
Slaughtered cow & 1.86 & 1.64 & 2.30 \\
\hline
\end{tabular}

${ }^{1} \mathrm{RDC}=$ Red Dairy Cattle; HOL $=$ Holstein. 
Table 3. Mean phenotypes for 305-d milk yield $(\mathrm{kg})$ within breed and production environment

\begin{tabular}{lccccccc}
\hline & \multicolumn{3}{c}{ Red Dairy Cattle } & & \multicolumn{3}{c}{ Holstein } \\
\cline { 2 - 3 } \cline { 6 - 8 } Trait & Denmark & Finland & Sweden & & Denmark & Finland & Sweden \\
\hline Milk, first lactation & 7,217 & 7,477 & 7,755 & & 7,808 & 7,995 & 8,558 \\
Milk, second lactation & 7,891 & 8,528 & 8,470 & & 8,863 & 9,162 & 9,843 \\
Milk, third lactation & 8,212 & 8,902 & 8,790 & & 9,239 & 9,648 & 10,074 \\
Protein, first lactation & 254 & 258 & 271 & & 260 & 268 & 284 \\
Protein, second lactation & 280 & 293 & 296 & & 299 & 309 & 326 \\
Protein, third lactation & 289 & 300 & 303 & & 308 & 320 & 331 \\
Fat, first lactation & 303 & 320 & 335 & & 317 & 311 & 337 \\
Fat, second lactation & 333 & 361 & 363 & & 361 & 356 & 389 \\
Fat, third lactation & 346 & 377 & 377 & & 379 & 378 & 403 \\
\hline
\end{tabular}

from milk production, beef production, and sale of surplus heifers. Revenue of beef production came both from fattening of young bulls and culling of heifers and cows. Costs can be divided into fixed costs and variable costs. Only variable costs were considered in the model. The cost of labor was set to $€ 19.60 / \mathrm{h}$ in all production environments. We only included the saved or extra working hours that were related to changes of the breeding goal traits we wanted to study.

\section{Milk Production}

Economic values were derived for 3 milk production traits: milk yield, protein yield, and fat yield. The mean phenotypes for milk production were based on records from the milk recording systems in Denmark, Finland, and Sweden (Table 3).

Milk yield at cow level was transformed to milk yield at herd level because profit from milk production depended on the average milk yield from both cows with and without a subsequent lactation. The transformation of 305-d milk yield was done by means of a lactation curve model (Skjøth and Trinderup, 2005) in combination with the estimated herd structure, the distribution of different lactations, and the number of days in milk for culled cows. Thus, milk yield, protein yield, and fat yield were calculated on a daily basis and summed over the number of days in milk. The lactation curve model formed the basis for the calculations of revenue from milk production, feed requirements, and finally feed costs. The assumed milk prices were based on the national milk prices ex farm (Table 4).

\section{Beef Production}

Economic values were derived for 2 beef production traits: (1) net daily gain and (2) EUROP conformation score. The economic values of beef production were only derived for young bulls. The mean phenotypes for beef production are shown in Table 5 .
In Denmark, one half of the bulls were slaughtered as bull calves and the other half were slaughtered as young bulls. In Finland and Sweden, all bulls were slaughtered as young bulls. The assumed prices of slaughtered bulls are shown in Table 6.

\section{Fertility}

Economic values were derived for 5 fertility traits: (1) days from first to last insemination (IFL) for heifers; (2) number of inseminations (NI) for heifers; (3) days from calving to first insemination (ICF) for cows; (4) IFL for cows; and (5) NI for cows. These variables were modeled through changes in conception rate. The mean phenotypes for fertility in heifers and cows were based on records from the national cattle databases reported by AI technicians (Table 7).

The economic values for fertility are derived by simulating an insemination sequence up to a maximum number of inseminations (potential inseminations $=$ number of heats). At the beginning of the simulations, all heifers are inseminated at the average age at first insemination (specific for country and breed) and all cows are inseminated after the average number of ICF (specific for country and breed). Then, the simulation continues heat by heat (coming regularly in 21-d intervals) calculating average numbers of pregnant animals, nonpregnant animals, inseminated animals, and not inseminated animals. At a specified heat (potential AI) the simulation is stopped and the total results are summarized. The economic consequences are expressed via change in calving interval, which has an effect on yearly milk production per cow and on average culling rate.

Table 4. Assumed milk prices $(€ / \mathrm{kg})$ for the 3 production environments

\begin{tabular}{lccc}
\hline Price & Denmark & Finland & Sweden \\
\hline Milk & -0.020 & 0.052 & -0.020 \\
Fat & 3.21 & 2.40 & 3.21 \\
Protein & 5.45 & 6.50 & 5.45 \\
\hline
\end{tabular}


Table 5. Mean phenotypes for production of slaughtered young bulls within breed and production environment

\begin{tabular}{|c|c|c|c|c|c|c|}
\hline \multirow[b]{2}{*}{ Item } & \multicolumn{3}{|c|}{ Red Dairy Cattle } & \multicolumn{3}{|c|}{ Holstein } \\
\hline & Denmark & Finland & Sweden & Denmark & Finland & Sweden \\
\hline Age at slaughter (d) & 376 & 627 & 592 & 372 & 627 & 594 \\
\hline Live weight $(\mathrm{kg})$ & 469 & 670 & 640 & 457 & 670 & 651 \\
\hline Carcass weight (kg) & 245 & 335 & 313 & 233 & 335 & 319 \\
\hline Daily gain $(\mathrm{kg} / \mathrm{d})$ & 1.247 & 1.069 & 1.081 & 1.228 & 1.069 & 1.096 \\
\hline Net daily gain $(\mathrm{kg} / \mathrm{d})$ & 0.652 & 0.523 & 0.529 & 0.626 & 0.523 & 0.537 \\
\hline EUROP conformation (point, 1-15) & 4.85 & 4.8 & 5.06 & 3.81 & 4.1 & 4.21 \\
\hline
\end{tabular}

To avoid double counting, costs of AI were assumed to be zero in the economic value of IFL. The final economic value of NI was the difference between the economic value of NI including costs of $\mathrm{AI}$ and the economic value of NI assuming no costs of AI. The costs of AI included an AI technician's fee plus handling and distribution of semen. Costs of selection; for example, payment to breeders, testing, and evaluation, were not included. The costs of AI were nearly the same in the 3 production environments (€19 to 21 /insemination). The time spent on heat detection and AI was assumed to be $42 \mathrm{~s} / \mathrm{d}$ per animal in the heat observation period and $0.25 \mathrm{~h} /$ insemination per animal, respectively.

\section{Health}

Economic values were derived for 5 groups of diseases: (1) mastitis; (2) metabolic diseases; (3) feet and leg diseases; (4) early reproductive diseases; and (5) late reproductive diseases. The phenotypic levels of treatment for diseases were based on records from the national databases reported by veterinarians (Table 8 ).

Costs of mastitis and other diseases were calculated as costs per incidence multiplied by the number of incidences. The costs per incidence included veterinary treatment, working hours for the dairy farmer, and discarded milk (Tables 9 and 10).

It is compulsory to discard milk from antibiotictreated cows. For that reason, milk was discarded: 6.75 $\mathrm{d}$ for mastitis, $1.80 \mathrm{~d}$ for metabolic diseases, $2.20 \mathrm{~d}$ for feet and leg diseases, and $3.90 \mathrm{~d}$ for early reproductive diseases. It was assumed that late reproductive diseases were not treated with antibiotics because they have a hormonal cause.

\section{Stillbirth and Calving Ease}

The phenotypic levels for stillbirth and calving ease were based on records from the national databases reported by dairy farmers (Table 11). Stillbirth and calving ease were considered separately for first-parity and later parity cows. Stillbirth was considered to be a categorical trait with 2 classes. Calving ease fell into 4 groups: (1) easy without assistance; (2) easy with assistance; (3) difficult without veterinary assistance; and (4) difficult with veterinary assistance. Group 4 included caesarean and dissection. The frequency distribution of the 4 groups served as the basis for the calculations. The thresholds between the groups were determined on the assumption that the liability $(l)$ was normally distributed $[l \sim \mathrm{N}(0,1)]$.

Stillbirth results in loss of earnings from raising heifers and young bulls, extra working hours, and costs of destruction. The working hours were $0.25 \mathrm{~h} /$ stillborn calf in Denmark and Sweden and $0.75 \mathrm{~h} /$ stillborn calf in Finland.

Costs of calving difficulty comprised extra working hours, veterinary assistance, and discarded milk. Costs of subsequent complications were included in costs of other diseases. For all breeds and production environments, the working hours were $0.20 \mathrm{~h} /$ incidence for an easy calving and $1.5 \mathrm{~h} /$ incidence for a difficult calving without veterinary assistance. In addition, dairy farmers were assumed to spend $3.35 \mathrm{~h}$ on a difficult calving with veterinary assistance in Denmark and Sweden and $3.70 \mathrm{~h}$ in Finland. The veterinary costs of a difficult calving with veterinary assistance were assumed to be $€ 260$ /incidence in Denmark and Finland and €312/ incidence in Sweden. It was also assumed that $20 \%$ of the group 4 cases required caesarean or dissection and

Table 6. Assumed prices of slaughtered males and form score for the 3 production environments

\begin{tabular}{|c|c|c|c|}
\hline Item & Denmark & Finland & Sweden \\
\hline Bull calves ( $€ / \mathrm{kg}$ of carcass) & 3.12 & - & - \\
\hline Young bulls (€/kg of carcass) & 2.48 & 3.21 & 3.10 \\
\hline EUROP conformation ( $€ /$ point $)^{1}$ & 0.10 & 0.09 & 0.09 \\
\hline
\end{tabular}

${ }^{1}$ The value of 1 unit derivation in EUROP conformation score per kilogram of carcass weight. 
Table 7. Mean phenotypes for fertility in heifers and cows within breed and production environment

\begin{tabular}{|c|c|c|c|c|c|c|}
\hline Item & \multicolumn{3}{|c|}{ Red Dairy Cattle } & \multicolumn{3}{|c|}{ Holstein } \\
\hline Age at first insemination, heifers (d) & 537 & 549 & 549 & 517 & 492 & 544 \\
\hline Estrus detection rate, heifers (\%) & 60.0 & 65.0 & 65.0 & 55.0 & 67.5 & 65.0 \\
\hline Interval from first to last insemination, heifers (IFL; d) & 15.3 & 17.9 & 17.9 & 22.2 & 15.7 & 17.6 \\
\hline Number of inseminations, heifers (NI) & 1.45 & 1.57 & 1.57 & 1.63 & 1.51 & 1.56 \\
\hline Estrus detection rate, cows (\%) & 40.0 & 37.5 & 45.0 & 35 & 37.5 & 40 \\
\hline Interval from first to last insemination, cows (IFL; d) & 29.8 & 42.2 & 32.4 & 41.7 & 38.9 & 39.2 \\
\hline Number of inseminations, cows (NI) & 1.70 & 1.99 & 1.82 & 1.95 & 1.91 & 1.95 \\
\hline Gestation length, cows (d) & 282 & 279 & 280 & 281 & 279 & 280 \\
\hline Calving interval (d) & 388 & 409 & 400 & 403 & 405 & 414 \\
\hline
\end{tabular}

thereby higher costs. In all production environments, milk was discarded for $1.2 \mathrm{~d}$ in response to a difficult calving with veterinary assistance.

\section{Longevity}

The economic value of longevity represents the value of improving life expectancy by $1 \mathrm{~d}$. The average culling rate within lactation, defined as the percentage of cows within a lactation that do not survive to the next lactation, served as the basis for the derivations. The mean phenotypes for longevity were based on records from the milk recording systems in Denmark, Finland, and Sweden (Table 12).
The herd structure changes if longevity is improved. Thus, the cows in the herd become older and thereby more profitable. In addition, it may be possible to purchase fewer heifers or to sell a larger surplus of heifers. These changes in the economic circumstances were taken into account in the derivation of an economic value of longevity.

\section{Workability}

Economic values were derived for 2 conformation traits: (1) feet and legs, and (2) udder. These main traits were treated as all other phenotypes in the analyses even though each of them consists of several

Table 8. Number of treatments (per 100 animals) for mastitis, metabolic diseases, feet and leg diseases, early reproductive diseases and late reproductive diseases, within breed and production environment

\begin{tabular}{|c|c|c|c|c|c|c|}
\hline \multirow[b]{2}{*}{ Item } & \multicolumn{3}{|c|}{ Red Dairy Cattle } & \multicolumn{3}{|c|}{ Holstein } \\
\hline & Denmark & Finland & Sweden & Denmark & Finland & Sweden \\
\hline Mastitis, early in first lactation ${ }^{1}$ & 23.5 & 10.5 & 8.0 & 19.1 & 14.7 & 10.0 \\
\hline Mastitis, late in first lactation ${ }^{2}$ & 17.1 & 9.4 & 7.3 & 18.8 & 14.8 & 10.6 \\
\hline Mastitis, second lactation ${ }^{3}$ & 32.2 & 17.6 & 12.7 & 36.6 & 22.6 & 18.4 \\
\hline Mastitis, third or later lactation ${ }^{3}$ & 40.0 & 22.5 & 17.9 & 45.1 & 28.2 & 23.9 \\
\hline Metabolic diseases, first lactation ${ }^{3}$ & 3.4 & 3.1 & 2.2 & 4.4 & 5.9 & 2.2 \\
\hline Metabolic diseases, second lactation ${ }^{3}$ & 6.4 & 5.2 & 4.7 & 6.1 & 7.6 & 5.1 \\
\hline Metabolic diseases, third or later lactation ${ }^{3}$ & 15.5 & 12.5 & 11.2 & 13.2 & 17.4 & 12.8 \\
\hline Feet and leg diseases, first lactation ${ }^{3}$ & 7.9 & 2.3 & 2.4 & 8.2 & 2.6 & 3.5 \\
\hline Feet and leg diseases, second lactation ${ }^{3}$ & 5.4 & 1.3 & 1.7 & 6.1 & 1.8 & 2.3 \\
\hline Feet and leg diseases, third or later lactation ${ }^{3}$ & 7.1 & 1.6 & 1.9 & 7.3 & 2.2 & 3.0 \\
\hline Early reproductive diseases, first lactation ${ }^{4}$ & 9.6 & 2.6 & 1.4 & 10.8 & 4.5 & 3.1 \\
\hline Early reproductive diseases, second lactation ${ }^{4}$ & 11.8 & 2.8 & 2.3 & 11.8 & 3.5 & 3.3 \\
\hline Early reproductive diseases, third or later lactation ${ }^{4}$ & 15.2 & 3.5 & 2.9 & 14.3 & 4.0 & 4.0 \\
\hline Late reproductive diseases, first lactation ${ }^{5}$ & 0.7 & 15.1 & 4.9 & 1.5 & 14.0 & 7.9 \\
\hline Late reproductive diseases, second lactation ${ }^{5}$ & 1.4 & 14.6 & 5.3 & 2.2 & 13.2 & 7.1 \\
\hline Late reproductive diseases, third or later lactation ${ }^{5}$ & 5.2 & 16.2 & 5.6 & 4.7 & 13.3 & 6.7 \\
\hline
\end{tabular}

${ }^{1} 15 \mathrm{~d}$ before calving to $50 \mathrm{~d}$ after calving.

${ }^{2} 51$ to 305 d after calving.

${ }^{3} 15$ d before calving to 305 d after calving.

${ }^{4} 15 \mathrm{~d}$ before calving to $40 \mathrm{~d}$ after calving.

${ }^{5} 41$ to 305 d after calving. 
Table 9. Assumed veterinary costs including fee and medicine $(€ /$ incidence) for the 3 production environments

\begin{tabular}{lccc}
\hline Disease & Denmark & Finland & Sweden \\
\hline Mastitis & 135 & 135 & 162 \\
Metabolic diseases & 85 & 102 & 102 \\
Feet and leg diseases & 75 & 90 & 90 \\
Early reproductive diseases & 95 & 95 & 114 \\
Late reproductive diseases & 58 & 70 & 70 \\
\hline
\end{tabular}

linear traits in real life; for example, udder depth, fore udder attachment, and central ligament. The mean phenotypes for the linear traits were based on records from the national cattle databases reported by classifiers. The costs of conformation were only comprised of working hours. In Denmark, the relationship between conformation and time usage was studied by means of a farmer survey. The results of this survey formed the basis for the assumptions in this study. Thus, if all linear traits were scored 1 point less than the optimum value then the extra working hours were $9 \mathrm{~s} / \mathrm{d}$ per cow for feet and legs and $13 \mathrm{~s} / \mathrm{d}$ per cow for udder. Traditionally, an economic value for body conformation has been derived. However, based on the survey no extra working hours are related to the body conformation traits.

Economic values were also derived for milking speed and temperament. If milking speed and temperament were scored 1 point less than the optimum value then the extra working hours were $9 \mathrm{~s} / \mathrm{d}$ per cow for milking speed and $4 \mathrm{~s} / \mathrm{d}$ per cow for temperament.

\section{Economic Values}

We chose a fixed number of cows as base of evaluation and profit maximization as the interest of selection. First, the model was run with all traits equal to the mean phenotypes. Then, the model was run after changing the level of each trait from the mean phenotypes individually. Economic values were derived by comparing profit before and after changing the level of each trait. The economic value of a given trait only includes the direct effect of this trait as the correlated effects are accounted for when economic values are derived for these traits. The economic values were not discounted to present values. Common Nordic economic values were calculated as the average of the economic values for the 3 production environments.

\section{Rank Correlations}

Spearman rank correlations between Danish, Swedish, and Finnish bulls evaluated on the basis of a national breeding goal and a joint breeding goal were estimated by means of the PROC CORR statement in SAS (SAS Institute Inc., Cary, NC). The bulls were born in 2006 and 2007 and registered as RDC or Holstein. The total merit indices (TMI) were based on the official breeding values predicted by NCGE. The bulls had official EBV for all traits. The index weights were based on the economic values for all individual traits and standardized to achieve a standard deviation of 10 index units for AI bulls in the base population. The base population consists of AI bulls from Denmark, Finland, and Sweden born in 1997 and 1998. Correlations were estimated for 441 RDC bulls and 843 Holstein bulls.

\section{RESULTS AND DISCUSSION}

\section{Economic Value of Individual Traits}

Economic values for the breeding goal traits in Euros per unit for RDC and Holstein in Denmark, Finland, and Sweden and the average economic values are given in Tables 13 and 14. Genetic standard deviations for the breeding goal traits are also included in Tables 13 and 14 to judge and compare the economic values.

For both RDC and Holstein, Finland had the highest economic values for milk and the lowest economic values for fat (Tables 13 and 14) due to differences in milk price and feed costs. The economic values for beef production were only derived for bull calves and young bulls; however, it is important to keep in mind that the improvements of net daily gain and EUROP conformation score also have an effect on the slaughter value of heifers and cows. For both RDC and Holstein, the economic values for net daily gain were highest in

Table 10. Working hours (h/incidence) for the dairy farmer as a result of veterinary treatment of diseases for the 3 production environments

\begin{tabular}{lccc}
\hline Disease & Denmark & Finland & Sweden \\
\hline Mastitis & 1.44 & 2.51 & 1.44 \\
Metabolic diseases & 1.25 & 1.65 & 1.25 \\
Feet and leg diseases & 1.43 & 1.87 & 1.43 \\
Early reproductive diseases & 1.08 & 1.78 & 1.08 \\
Late reproductive diseases & 0.75 & 1.00 & 0.75 \\
\hline
\end{tabular}


Table 11. Mean phenotypes (\%) for stillbirth and calving ease within breed and production environment

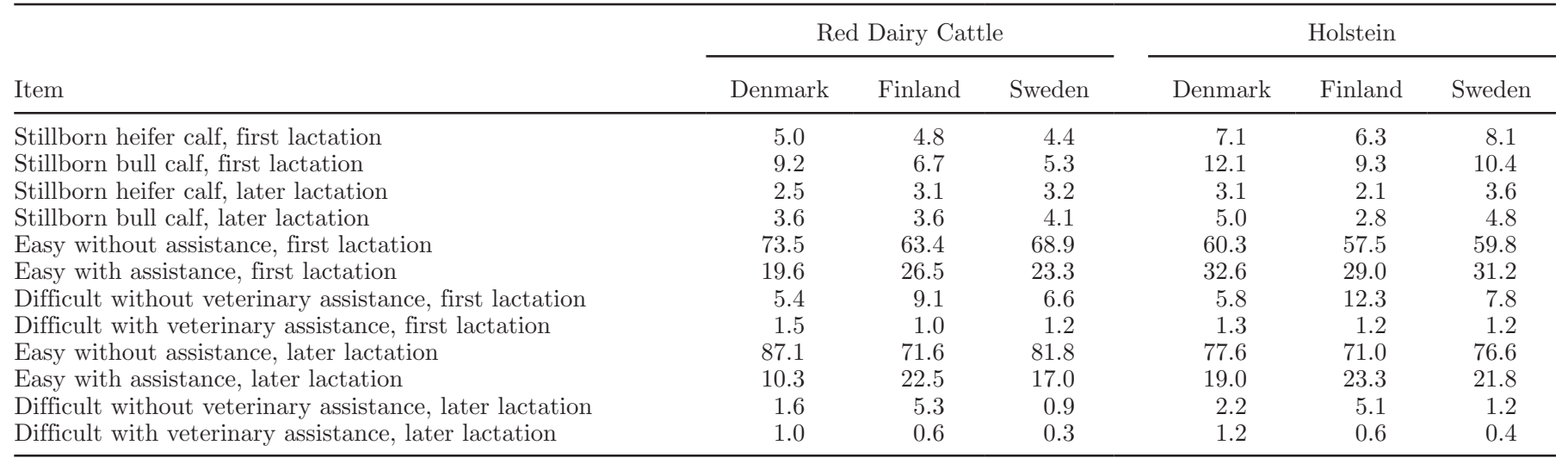

Sweden. This is due to a favorable ratio between carcass and feed prices. Denmark had the lowest economic values for EUROP conformation score for both RDC and Holstein, because $50 \%$ of the slaughtered males are bull calves with low carcass weight. In Finland and Sweden, young bulls are slaughtered with a high carcass weight, and the value of one EUROP conformation score depends on carcass weight.

The economic value for stillbirth is, among other things, influenced by the number of young stock that can be raised. Thus, the low economic values for stillbirth in both Danish breeds are explained by the fact that the price of slaughtered young bulls is lowest in Denmark (Tables 13 and 14). For both RDC and Holstein, the economic values for calving ease in later lactations were highest in Denmark. The reason is that the frequency of calving difficulty is highest in Denmark. The effect of improved fertility on profit was mostly due to a change in calving interval which, in turn, had an effect on the annual milk production/cow. Improved fertility also saved on costs of insemination and time spent on heat detection and insemination. For RDC, the economic values for days from first to last insemination and number of inseminations (both in cows) were highest in Finland. The reason is that the phenotypic levels for these 2 traits are highest in Finland. For RDC, the overall economic value for mastitis in all lactations was highest in Denmark. The reason is that the incidence of mastitis is highest in Denmark, which results in high costs of mastitis.
Denmark had the highest economic value for days from first to last insemination in Holstein heifers. This is linked to the fact that the phenotypic level for this trait was highest in Denmark. For Holstein, the economic values for other diseases were high in Finland. One possible explanation is that the costs of diseases as well as the incidence of some of the groups of diseases were higher in Finland than in the other countries.

\section{Rank Correlations}

The results for both RDC and Holstein indicated a very strong positive relationship between the ranks bulls obtained for a national breeding goal and a joint breeding goal (Table 15). For RDC, the rank correlation between the Finnish breeding goal and the joint breeding goal (0.987) was the lowest among the correlations between a national breeding goal and the joint breeding goal. The consequence is that 2 bulls that appear on the top 30 list for the Finnish breeding goal do not appear on the top 30 list for the joint breeding goal. For Holstein, the rank correlations were very close to unity. Thus, a joint breeding goal within breed is feasible for Denmark, Finland, and Sweden. However, the derivations are based on average production systems within countries and for that reason they may not account for extreme production systems.

\section{General Discussion}

This study confirmed the hypothesis that the development of a joint breeding goal for each of the major

Table 12. Mean phenotypes (\%) for longevity within breed and production environment

\begin{tabular}{lcccccccc}
\hline & \multicolumn{3}{c}{ Red Dairy Cattle } & & \multicolumn{3}{c}{ Holstein } \\
\cline { 2 - 3 } \cline { 7 - 9 } Item & Denmark & Finland & Sweden & & Denmark & Finland & Sweden \\
\hline Culling rate, first lactation & 33 & 25 & 34 & & 30 & 25 & 31 \\
Culling rate, second lactation & 38 & 35 & 39 & & 40 & 35 & 40 \\
Culling rate, later lactations & 43 & 50 & 44 & & 50 & 50 & 50 \\
\hline
\end{tabular}


Table 13. Genetic standard deviations (SD) and economic values for the breeding goal traits for Red Dairy Cattle in Denmark, Finland, and Sweden and the average economic values (Nordic); genetic SD are, by default, from the description of national genetic evaluation systems from Interbull (Interbull, 2014)

\begin{tabular}{|c|c|c|c|c|c|}
\hline Trait & SD & Denmark & Finland & Sweden & Nordic \\
\hline Milk $(€ / \mathrm{kg})$ & 807 & -0.049 & 0.015 & -0.054 & -0.029 \\
\hline Fat $(€ / \mathrm{kg})$ & 33.8 & 1.63 & 0.67 & 1.69 & 1.33 \\
\hline Protein $(€ / \mathrm{kg})$ & 27.1 & 4.35 & 5.49 & 4.61 & 4.81 \\
\hline Net daily gain $(€ / \mathrm{kg} / \mathrm{d})$ & $0.049^{3}$ & 204.6 & 197.5 & 266.2 & 222.8 \\
\hline EUROP form score (€/point, $1-15)$ & $0.54^{3}$ & 11.8 & 14.5 & 14.6 & 13.6 \\
\hline Stillbirth, first lactation ${ }^{1}(€ / \%$-units $)$ & $0.08 \mid 0.06$ & 1.71 & 2.09 & 2.22 & 2.01 \\
\hline Calving ease, first lactation ${ }^{1}(€ /$ point, $1-4)$ & $0.20 \mid 0.17$ & 12.95 & 9.02 & 12.21 & 11.35 \\
\hline Stillbirth, later lactations ${ }^{1}(€ / \%$-units $)$ & $0.04 \mid 0.04^{4}$ & 2.99 & 3.68 & 3.44 & 3.37 \\
\hline Calving ease, later lactations ${ }^{1}(€ /$ point, $1-4)$ & $0.10 \mid 0.10^{4}$ & 23.66 & 12.93 & 10.46 & 15.62 \\
\hline First to last insemination, heifer $(€ / d)$ & $4.3^{5}$ & 0.61 & 0.66 & 0.56 & 0.61 \\
\hline No. of inseminations, heifer ( $€$ /insemination) & $0.13^{5}$ & 9.26 & 10.46 & 10.69 & 10.14 \\
\hline Calving to first insemination, cow $(€ / d)$ & 5.5 & 0.56 & 0.51 & 0.62 & 0.56 \\
\hline First to last insemination, cow $(€ / d)$ & 8.1 & 1.35 & 2.56 & 1.41 & 1.78 \\
\hline No. of inseminations, cow $(€ /$ insemination $)$ & $0.18^{5}$ & 17.94 & 43.41 & 20.38 & 27.24 \\
\hline Mastitis, first lactation $^{2}(€ / \%$-units $)$ & - & 1.44 & 1.41 & 1.52 & 1.46 \\
\hline Mastitis, second lactation ${ }^{2}(€ / \%$-units $)$ & - & 1.07 & 1.08 & 1.00 & 1.05 \\
\hline Mastitis, third+ lactation ${ }^{2}(€ / \%$-units) & - & 1.63 & 1.44 & 1.41 & 1.49 \\
\hline Mastitis, all lactations $^{2}(€ / \%$-units $)$ & 0.047 & 4.14 & 3.93 & 3.93 & 4.00 \\
\hline Metabolic diseases $^{2}(€ / \%$-units $)$ & $0.03^{6}$ & 1.77 & 1.98 & 1.85 & 1.87 \\
\hline Feet and leg diseases ${ }^{2}(€ / \%$-units $)$ & $0.03^{6}$ & 1.78 & 1.77 & 1.55 & 1.70 \\
\hline Early reproductive diseases ${ }^{2}(€ / \%$-units $)$ & $0.05^{6}$ & 1.92 & 1.94 & 1.91 & 1.93 \\
\hline Late reproductive diseases $^{2}(€ / \%$-units) & $0.05^{6}$ & 0.92 & 1.14 & 1.06 & 1.04 \\
\hline Average culling $(€ / d)$ & 83.5 & 0.43 & 0.41 & 0.32 & 0.38 \\
\hline Udder (€/point, 1-9) & 0.76 & 25.5 & 25.5 & 25.5 & 25.5 \\
\hline Feet and legs $(€ /$ point, $1-9)$ & 0.55 & 17.0 & 17.0 & 17.0 & 17.0 \\
\hline Milking speed (€/point, 1-9) & 0.73 & 17.0 & 17.0 & 17.0 & 17.0 \\
\hline Temperament (€/point, 1-9) & 0.36 & 8.5 & 8.5 & 8.5 & 8.5 \\
\hline
\end{tabular}

${ }^{1}$ Direct and maternal estimates before and after the vertical bar, respectively.

${ }^{2}$ The derived economic value is the value of 1 percentage unit change in incidence corrected for the number of animals in the different groups.

${ }^{3}$ Johansson et al. (2009).

${ }^{4}$ U. S. Nielsen (Knowledge Center for Agriculture, Aarhus N, Denmark, personal communication).

${ }^{5}$ Roxström et al. (2001).

${ }^{6}$ Christensen (2003).

dairy cattle breeds across Denmark, Finland, and Sweden would be an advantage. The results of this study formed the basis for the Nordic TMI (NTM) which has been brought into use in Denmark, Finland, and Sweden for the Nordic Holstein breed and the Nordic Red breed (Pedersen et al., 2008).

Economic values are rarely known without errors because models for derivation of economic values and values of different traits in future production systems and markets are subject to uncertainty (Gibson and Dekkers, 2009). However, we have tried to limit these uncertainties by using market prices from spring 2007 . Market prices from spring 2007 were used because the relationship between milk and feed prices had been stable over the last $20 \mathrm{yr}$. However, both feed prices and milk prices started to fluctuate in the fall of 2007 and no end to these fluctuations was in sight when the project started. Furthermore, sensitivity analyses were performed covering 8 alternative scenarios: (1) sales value of milk was increased by $€ 0.03 / \mathrm{kg}$; (2) feed cost was increased by $10 \%$; (3) sales value of beef was increased by $10 \%$; (4) the price differences between EUROP form classes were increased by $10 \%$; (5) the value of a pregnant heifer was reduced to the slaughter value; (6) labor costs were increased by $10 \%$; (7) veterinarian costs were increased by $10 \%$; and (8) €20 was added to the cost per AI. In general, the economic values were reasonably robust to changes in the assumptions

In this study, the economic values were derived by means of an objective method. However, before the TMI was put into practice, the index weights were discussed in relevant forums so that representatives of the AI organizations and the dairy farmers had the opportunity to discuss and change the index weights. One of the main subjects of debate was the expectations about future economic development. These expectations should ideally be included in the index weight derivation to ensure that characteristics, production level, and composition of future populations meet expected future prices and demands (Groen et al., 1997). These expectations were, however, not included in the present derivations, which were based on the economic 
Table 14. Genetic standard deviations (SD) and economic values for the breeding goal traits for Holstein in Denmark, Finland, and Sweden and the average economic values (Nordic); genetic SD are, by default, from the description of national genetic evaluation systems from Interbull (Interbull, 2014)

\begin{tabular}{|c|c|c|c|c|c|}
\hline Trait & $\mathrm{SD}$ & Denmark & Finland & Sweden & Nordic \\
\hline Milk $(€ / \mathrm{kg})$ & 831 & -0.049 & 0.012 & -0.052 & -0.030 \\
\hline Fat $(€ / \mathrm{kg})$ & 32.7 & 1.62 & 0.59 & 1.64 & 1.28 \\
\hline Protein $(€ / \mathrm{kg})$ & 25.0 & 4.34 & 4.95 & 4.51 & 4.60 \\
\hline Net daily gain $(€ / \mathrm{kg} / \mathrm{d})$ & $0.041^{3}$ & 187.2 & 193.8 & 222.7 & 201.3 \\
\hline EUROP form score $(€ /$ point, $1-15)$ & $0.54^{3}$ & 11.5 & 15.3 & 14.6 & 13.8 \\
\hline Stillbirth, first lactation ${ }^{1}(€ / \%$-units) & $0.11 \mid 0.10$ & 1.7 & 2.2 & 2.2 & 2.0 \\
\hline Calving ease, first lactation ${ }^{1}(€ /$ point, $1-4)$ & $0.24 \mid 0.21$ & 11.2 & 10.1 & 11.7 & 11.0 \\
\hline Stillbirth, later lactations $^{1}(€ / \%$-units $)$ & $0.04 \mid 0.04^{4}$ & 2.7 & 3.9 & 3.3 & 3.3 \\
\hline Calving ease, later lactations ${ }^{1}(/$ point, $1-4)$ & $0.17 \mid 0.13^{4}$ & 20.0 & 13.5 & 11.1 & 14.9 \\
\hline First to last insemination, heifer $(€ / d)$ & $4.2^{5}$ & 1.16 & 0.50 & 0.54 & 0.73 \\
\hline No. of inseminations, heifer ( $€$ /insemination) & $0.09^{5}$ & 9.05 & 10.97 & 10.50 & 10.17 \\
\hline Calving to first insemination, cow $(€ / d)$ & 6.5 & 0.43 & 0.81 & 0.61 & 0.62 \\
\hline First to last insemination, cow $(€ / d)$ & 7.2 & 2.63 & 2.41 & 2.00 & 2.35 \\
\hline No. of inseminations, cow (€/insemination) & $0.18^{6}$ & 39.13 & 36.11 & 31.40 & 35.55 \\
\hline Mastitis, first lactation ${ }^{2}(€ / \%$-units) & - & 1.45 & 1.50 & 1.56 & 1.50 \\
\hline Mastitis, second lactation ${ }^{2}(€ / \%$-units $)$ & - & 1.15 & 1.15 & 1.09 & 1.13 \\
\hline Mastitis, third lactation ${ }^{2}(€ / \%$-units) & - & 1.42 & 1.55 & 1.35 & 1.44 \\
\hline Mastitis, all lactations $^{2}(€ / \%$-units $)$ & 0.08 & 4.02 & 4.20 & 4.00 & 4.07 \\
\hline Metabolic diseases ${ }^{2}(€ / \%$-units $)$ & $0.03^{7}$ & 1.78 & 2.11 & 1.76 & 1.88 \\
\hline Feet and leg diseases ${ }^{2}(€ / \%$-units $)$ & $0.03^{7}$ & 1.77 & 1.88 & 1.62 & 1.75 \\
\hline Early reproductive diseases ${ }^{2}(€ / \%$-units $)$ & $0.05^{7}$ & 1.90 & 2.12 & 1.96 & 2.00 \\
\hline Late reproductive diseases ${ }^{2}(€ / \%$-units) & $0.05^{7}$ & 0.88 & 1.21 & 1.06 & 1.05 \\
\hline Average culling $(€ / d)$ & 83.8 & 0.51 & 0.63 & 0.42 & 0.51 \\
\hline Udder $(€ /$ point, $1-9)$ & 0.82 & 25.6 & 25.6 & 25.6 & 25.6 \\
\hline Feet and legs (€/point, 1-9) & 0.33 & 17.0 & 17.0 & 17.0 & 17.0 \\
\hline Milking speed $(€ /$ point, $1-9)$ & 0.67 & 17.0 & 17.0 & 17.0 & 17.0 \\
\hline Temperament (€/point, 1-9) & 0.48 & 8.5 & 8.5 & 8.5 & 8.5 \\
\hline
\end{tabular}

${ }^{1}$ Direct and maternal estimates before and after the vertical bar, respectively.

${ }^{2}$ The derived economic value is the value of 1 percentage unit change in incidence corrected for the number of animals in the different groups.

${ }^{3}$ Johansson et al. (2009).

${ }^{4}$ U. S. Nielsen (Knowledge Center for Agriculture, Aarhus N, Denmark, personal communication).

${ }^{5}$ Sørensen et al. (2013).

${ }^{6}$ Buch and Norberg (2008).

${ }^{7}$ Christensen (2003).

situation in spring 2007. Instead, the expectations were considered afterward, and political changes were made before the economic values were used by the industry. Another subject of debate was the incorporation of ecological, social, and ethical aspects in the breeding goal. These aspects were not included in the model; however, we believe that they are important, as pointed out by Groen et al. (1997), Olesen et al. (2000), and Nielsen (2004). For that reason, these aspects were discussed and to some extent included in the index weights.

In this study, different production environments within countries were not considered; for example, the production environment in northern Finland and an organic production environment. Instead, average production environments for each country were used. Thus, the national economic values do not cover the entire range of production environments. However, Nordic TMI covers the majority of the Nordic dairy producers as the breeding goal is balanced with sub- stantial emphasis on health, fertility, milk production, and longevity.

The economic value of a trait is defined as the effect of a marginal change in the genetic level of the trait in question on profit, keeping all other breeding goal traits constant. However, it is difficult to fulfill this assumption for some of the functional traits, among them fertility, as some structural relationships exist between, for instance, fertility, culling rate, and milk yield, and

Table 15. Rank correlations between bulls selected for a Danish, Finnish, Swedish, or joint breeding goal (Nordic; RDC above the diagonal and Holstein below the diagonal)

\begin{tabular}{lcccc}
\hline Item & Denmark & Finland & Sweden & Nordic \\
\hline Denmark & - & 0.971 & 0.997 & 0.995 \\
Finland & 0.998 & - & 0.976 & 0.987 \\
Sweden & 0.996 & 0.998 & - & 0.996 \\
Nordic & 0.999 & 0.999 & 0.998 & - \\
\hline
\end{tabular}


these relationships must be included in the model. Wolfova and Wolf (2013) suggest that relationships among traits should be taken into account when these relationships are structural and caused by changes in the age structure of the herd but not when they are caused by genetic correlations between traits. In this study, it was assumed that an improved conception rate does not influence culling rate per year but it increases number of calvings per year. This means that the number of calves born and the annual milk production per herd were improved as a result of improved fertility. In addition, fertility had an effect on milk yield because daily milk yield will be reduced by 4 to $6 \mathrm{~kg}$ from d 120 after conception and onward.

Longevity is highly affected by improvements of other functional traits, such as fertility, udder health, resistance against other diseases, feet and legs, and udder. If improvement of these traits decreases involuntary culling or enables another focus on selection then this has an economic value. However, these structural relationships were not included in the program or in the economic values of the other functional traits. For that reason, one could argue that the economic values of the functional traits are underestimated and that the economic value of longevity is too high if we interpret longevity as residual longevity.

The structural interactions, which were not taken into consideration in the present study, can for a great part be considered using mechanistic, dynamic, and stochastic dairy herd models that simulate the production and state changes of dairy cows and young stock. However, correlated genetic responses are also included in this type of model. Therefore, it is not possible to keep all other traits constant when one trait is changed. This must afterward be accounted for through multiple regression.

\section{CONCLUSIONS}

This study concludes that the development of a joint breeding goal for each of the major dairy cattle breeds across Denmark, Finland, and Sweden is an advantage as rank correlations between Danish, Finnish, and Swedish TMI and a joint Nordic TMI are very high. The derived economic values are substantial for production, fertility, calving, and health traits reflecting a balanced breeding goal. The development of a joint breeding goal opens up the possibility for a joint breeding scheme and thereby higher genetic gain.

\section{REFERENCES}

Buch, L. H., and E. Norberg. 2008. Genetic analysis of protein yield, udder health, and female fertility in first-parity Danish Holstein cows. Acta Agric. Scand. A Anim. Sci. 58:5-9.
Christensen, L. G. 2003. Kvægavl-Teori og Praksis. 2nd ed. Biofolia, Frederiksberg, Denmark.

Gibson, J. P., and J. C. M. Dekkers. 2009. Economic selection indexes. Chapter 6 in Design and Economics of Animal Breeding strategies. Accessed August 14, 2014. http://www.anslab.iastate.edu/Class/ AnS652X/Chapter6.pdf.

Groen, A. F., T. Steine, J. J. Colleau, J. Pedersen, J. Pribyl, and N. Reinsch. 1997. Economic values in dairy cattle breeding, with special reference to functional traits. Report of an EAAP-working group. Livest. Prod. Sci. 49:1-21.

Interbull, 2014. National genetic evaluation forms provided by countries. Accessed May 1, 2014. https://wiki.interbull.org/public/ Nat_GE_Forms?action=print.

Johansson, K., U. S. Nielsen, J. Pösö, J. Å. Eriksson, and G. P. Aamand. Joint Nordic genetic evaluation of growth and carcass traits in dairy breeds. Proceedings of the 2009 Interbull meeting. Barcelona, Spain, August 21-24 2009.

Kolmodin, R. 2003.Reaction norms for the study of genotype by environment interaction in animal breeding. PhD Thesis. Swedish University of Agricultural Sciences, Uppsala.

Kulak, K., H. M. Nielsen, and E. Strandberg. 2004. Economic values for production and non-production traits in Nordic dairy cattle populations calculated by stochastic simulation. Acta Agric. Scand. A Anim. Sci. 54:127-138.

Lynch, M., and B. Walsh. 1998. Genetics and Analysis of Quantitative Traits. Sinauer Associates Inc., Sunderland, MA.

NAV. 2014. Excel program for calculation of economic weights used in NTM. Accessed April 29, 2014. http://www.nordicebv.info/NR/ rdonlyres/0BDB534F-8BAC-44ED-92BC-6758604178D1/0/TMI xls.

Nielsen, H. M. 2004. Economic values for production and functional traits in dairy cattle breeding goals derived by stochastic simulation. PhD Thesis. The Agricultural University, Copenhagen, Denmark.

Olesen, I., A. F. Groen, and B. Gjerde. 2000. Definition of animal breeding goals for sustainable production systems. J. Anim. Sci. $78: 570-582$.

Østergaard, V., and A. Neimann-Sørensen. 1989. Basis for choice of breeding goal and matching production system within dairy herds. Report no. 660. The National Institute of Animal Science, Foulum, Denmark.

Pedersen, J., M. K. Sørensen, M. Toivonen, J. Å. Eriksson, and G. P. Aamand. 2008. Report on economic basis for a Nordic total merit index. Accessed April 29, 2014. http://www.nordicebv.info/NR/ rdonlyres/B618C0E5-FF6F-4D31-8F86-B3CE4A140043/0/NAV_ TMI_report_lastversion_131108.pdf.

Roxström, A., E. Strandberg, B. Berglund, J. Emanuelsen, and J. Philipsson. 2001. Genetic and environmental correlations among female fertility traits and milk production in different parities of Swedish red and white dairy cattle. Acta Agric. Scand. A Anim. Sci. 51:7-14.

Sjaunja, L. O., L. Baevre, L. Junkkarinen, J. Pedersen, and J. Setälä. 1990. A Nordic proposal for an energy corrected milk (ECM) formula. Proc. International Committee for Recording the Productivity of Milk Animals. 27th session, Paris, France. International Committee for Animal Recording (ICAR), Rome, Italy.

Skjøth, F., and M. Trinderup. 2005. Standard laktationskurver til produktionskontrol. Report no. 116. Danish Agricultural Advisory Service, Danish Cattle, Skejby, Denmark.

Sørensen, L. H., A. C. Sørensen, T. Mark, and M. Kargo. 2013. Genetic parameters for fertility measurements in Holstein heifers-The activity tag Heatime makes a difference. Acta Agric. Scand. A Anim. Sci. 63:169-174.

Veerkamp, R. F., G. C. Emmans, A. R. Cromie, and G. Simm. 1995. Variance components for residual feed intake in dairy cows. Livest. Prod. Sci. 41:111-120.

Wolfova, M., and J. Wolf. 2013. Strategies for defining traits when calculating economic values for livestock breeding: A review. Animal 7:1401-1413. 